\title{
PENGEMBANGAN ETIKA SOSIAL MELALUI DESAIN INSTRUKSIONAL PENDIDIKAN AGAMA ISLAM (PAI) KONTEMPORER
}

\author{
Mukhibat
}

(Dosen PAI STAIN PONOROGO)

\begin{abstract}
This writing is expressions of the writer's irritated feeling of tenageers's social etique. It is indicated by their uncontrolled behavior in which they often conduct fighting with other tenageers. This event is the portrait of the defact on social life. To cope this condition, it is required for religion educators with students'parents and the society leaders to internalize values of social etiques. One of ways is by teaching integration of social etique with religion. Hence, educators on education must develop instructional designs. Contemporer of Islamic teaching can be realized through; (1)identify on their doubt on a particular value based on their need, (2) determine requirements and the alternative of problem solving, (3)choose the appropriate strategy of problem solving, (4)apply the strategy, (5)observe the effectiveness through evaluation, (6) revise the action. Beside that Islamic education teachers need to design the pattern of classroom management using socio emotional climate and practice the principle of effective classroom management such as identify students.
\end{abstract}

Keywords: Islamic ethic, instructional designs.

\section{A. PENDAHULUAN}

Paradigma gagasan tentang kemajuan ${ }^{\prime}$ masih sangat dominan dalam alam pikiran masyarakat modern. Diakui atau tidak, hal itu telah menjadi penyangga bagi kemajuan teknologi modern yang memiliki arti yang sangat vital bagi kelangsungan hidup manusia. Tetapi justru di titik ini pula berbagai kritik mulai banyak dilontarkan orang. Tatkala prestasi di bidang Iptek dijadikan satu-satunya acuan dan ukuran keberhasilan, maka

${ }^{1}$ Komaruddin Hidayat "Agama dan Kegalauan Masyarakat Modern" dalam M. Amin Akkas, Hassan M. Noer (ed), Kehampaan Spiritual Masyarakat Modern, Respon dan Transformasi Nilai-nilai Islam Munuju Masyarakat Madani, (Jakarta: Media Cita, 2000), 98. 
yang terjadi adalah proses pendangkalan kualitas hidup ${ }^{2}$. Nilai-nilai kehidupan seperti kebersamaan, solidaritas sosial, kasih sayang antar sesama mulai tergeser dari keprihatinan dan wacana keseharian ketika keserakahan pada materi yang disimbolkan oleh keberhasilan Iptek menjadi acuan yang dominan.

Pada sisi lain, orang juga menyesalkan hilangnya fungsi dan peranan agama yang seharusnya bisa menjadi pembimbing manusia dalam memahami dan menghayati nilai-nilai transendental untuk menumbuhkan nilai-nilai luhur pada kehidupan individual maupun sosial sehingga masyarakat modern tidak terjerat pada kebanggaan materi belaka. Jika kondisinya demikian, maka tawaran penyelesaian di rasa sangat penting untuk menangkal situasai kehampaan spiritual dan keterasingan.

Dalam konteks inilah peran fundamental agama mutlak diperlukan dalam semua aspek kehidupan baik individu maupun sosial. Menurut Zakiah Darajad ${ }^{3}$ agama merupakan kebutuhan psikis yang harus dipenuhi. Apalagi apabila peran dan fungsi agama tersebut berkaitan dengan moralitas bangsa ini, kenakalan remaja, pergaulan bebas, korupsi, dekadensi moral kesemuanya itu harus segera mendapatkan perhatian yang serius dari segenap lapisan masyarakat.

Jika Kesadaran akan pentingnya nilai-nilai agama, moral, dan etika sosial dalam kehidupan bangsa ini masih ada, maka tidak ada media lain yang paling bagus kecuali dengan pendidikan baik pendidikan formal maupun informal. Dunia pendidikan mempunyai peluang yang sangat besar untuk merealisasikannya. Ini berarti kesempatan emas bagi umat Islam untuk menjadikan pendidikan sebagai pilihan yang baik bagi pemeliharaan, penanaman dan penyebaran nilai-nilai Islam dalam kehidupan masyarakat Indonesia. Konsekuensinya, diperlukan upayaupaya yang dinamis, fleksibel dan serius dalam menggarap dunia pendidikan.

Kegiatan pendidikan yang dilaksanakan oleh umat Islam -atau apa yang sering disebut dengan pendidikan Islam- menjangkau semua interaksi

2 Ibid., Lihat juga Frans Magnis Suseno, "Pendidikan Budu Pekerti", dalam Ikhwanuddin Syarif, Dodo Murtadlo (ed), Pendidikan untuk Masyarakat Indonesia Baru, 70 tahun Prof, Dr. H.A.R. Tilaar, M..Sc.Ed., (Jakarta: Grasindo, 2002), 442.

3 Zakiah Darajad, Pendidikan Agama dalam Pembinaan Mental, (Jakarta: Bulan Bintang, 1982), 12 
edukatif, baik melalui jalur sekolah maupun luar sekolah. Kegiatan pendidikan Islam melalui jalur luar sekolah antara lain tercermin dalam kegiatan majelis ta lim, pengajian, pondok pesantren dan lain-lain. Sementara itu, pendidikan Islam melalui jalur sekolah antara lain diwujudkan dalam bentuk lembaga pendidikan Islam formal seperti MI, MTs, MA, IAIN/STAIN/PTAIS, dan pelajaran Pendidikan Agama Islam (PAI) di lembaga pendidikan (sekolah) umum. Keberadaan PAI dalam keseluruhan isi kurikulum di sekolah umum memang dijamin oleh UU No. 20 Tahun 2003 tentang Sistem Pendidikan Nasional bab X pasal 37 "Kurikulum pendidikan dasar dan menengah wajib memuat: a. pendidikan agama, Bahkan PAI merupakan salah satu mata pelajaran wajib yang harus diajarkan di setiap jalur, jenis dan jenjang pendidikan baik negeri maupun swasta.

Persoalannya, apakah pendidikan agama yang sekarang ini dilaksanakan telah benar-benar efektif. Jika jawabannya negatif maka diperlukan clinical remedey ${ }^{4}$ atau redesaian materi pelajaran agama agar sesuai dengan jiwa anak di era modern. Di sini perlu dilibatkan pakar masingmasing agama untuk menentukan kualitas materi dan pakar bidang pendidikan dan metodologi.

Fakta di lapangan menunjukkan, pendidikan agama di sekolah seringkali berjalan secara rutinitas dan birokratis. Rutinitas karena pendidikan agama berjalan menurut aturan atau ketentuan sesuai dengan situasi ruang dan waktu dan memperoleh porsi yang sangat kecil. Birokratis karena pendidikan agama diperlakukan sama dengan mata pelajaran lainnya yang seringkali memperolah intervensi birokratis dari aparat pelaksana pendidikan. Hal-hal negatif lain yang masih dijumpai, yaitu ketika agama yang menjadi wilayah publik yang terjadi bukan ajaran agama memberikan roh kepada dunia publik, melainkan begitu banyak politisasi agama yang justru memiskinkan agama. Yang lebih memprihatinkan lagi, beberapa tahun terakhir ini perkelahian antar pelajar dan remaja sering semakin marak terjadi.

Salah satu faktor yang menyebabkan rendahnya etika sosial tersebut adalah penggunaan pendekatan pembelajaran agama yang masih dilakukan secara tradisional sehingga kurang sesuai kebutuhan peserta

4 Hamid Fahmi, 'Negara, Pendidikan Agama, Moralitas Bangsa, dalam Darmanigtiyas, dkk. (peny). Membongkar Ideologi Pendidikan, Jelajah undang-Undang Sistem Pendidikan Nasional. (Yogyakarta: Resolusi Press, 2004), 53 
didik di era globalisasi. Hal ini disebabkan karena proses pembelajaran agama selama ini hanya menekankan pada transfer of knowledge dan bukan pada transfer of value, materi pembelajaran pendidikan agama lebih bersifat kognitif yakni berupa fakta-fakta yang harus dihafal oleh peserta didik, sehingga materi pelajaran PAI ditempatkan sama dengan materi pelajaran IPS, IPA, Biologi dan lain-lain.

Upaya untuk mengoptimalkan aspek-aspek yang berpengaruh dalam pembelajaran, salah satu cara yang dilakukan pemerintah adalah misalnya dengan melaksanakan pembaharuan kurikulukum, yang dikenal dengan Kurikulum Tingkat Satuan Pendidikan (KTSP), di mana seorang guru memiliki otonomi dalam mendesain kegiatan-kegiatan instruksional di kelas. Diharapkan dengan pendekatan ini bisa terungkap bagaimana sistem dan disain pembelajaran PAI di Sekolah Umum khususnya SMP sekaligus dengan berbagai dinamika dan problematika yang ada. Dengan menjadikan kegiatan instruksional PAI sebagai sistem, maka akan menjangkau pula berbagai komponen yang terlibat di dalamnya.

Kebijakan tersebut memberikan peluang dan sekaligus tantangan bagi guru-guru PAI untuk lebih memutakhirkan pembelajarannya sesuai dengan tuntutan perkembangan. Pemikiran untuk mengembangkan dan menyegarkan model-model pembelajaran PAI yang tepat merupakan hal yang sangat urgen. Melaui desain instruksional PAI, peserta didik diharapkan mereka semakin memiliki perasaan sosial yang tingi, memiliki rasa kasih sayang, toleransi, disiplin, jujur, kerja keras, dan saling menghormati antara yang satu dengan yang lainnya. Etika sosial membicarakan kewajiban manusia sebagai anggota umat manusia. ${ }^{5}$ Artinya secara sadar yang berpangkal dari hati nurani seseorang harus merasa berkewajiban untuk berbuat baik bagi kepentingan manusia yang lain, bukan kepentingan pribadi yang merugikan orang lain.

\section{B. PENGERTIAN ETIKA SOSIAL}

Istilah Etika berasal dari kata latin Ethic: arti sebenarnya ialah kebiasaan, habit, custom. Jadi dalam pengertian aslinya, apa yang disebutkan baik itu yang sesuai dengan kebiasaan masyarakat (dewasa) itu. Secara istilah etika ialah suatu ilmu yang membicarakan masalah perbuatan atau

5 A Qodri Azizy, Pendidikan (Agama) Untuk Membangun Etika Sosial, (Semarang: Aneka Ilmu, Semarang, 2002), 12 
tingkah laku manusia yang dapat dinilai baik dan yang jahat. $^{6}$ Sedang yang dimaksud dengan etika sosial ialah filsafat atau pemikiran kritis rasional tentang kewajiban dan tanggung jawab manusia sebagai angota umat manusia. ${ }^{7}$ Dengan demikian maka etika sosial membicarakan kewajiban manusia sebagai anggota umat manusia.

Sebagaimana diketahui bahwa manusia di samping sebagai makhluk individu, juga merupakan makhluk sosial, yang berkecenderungan untuk selalu dapat hidup bersama orang lain. Dan ketika seseorang merasa berkewajiban, itu berarti bahwa ia telah dan sedang memberi hak kepada orang lain. Di sini harus seimbang antara hak dan kewajiban yang harus dilakukan oleh seseorang sebagai anggota masyarakat, dengan keseimbangan akan menghasilkan keteraturan sosial.

Nilai-nilai yang mengandung keteraturan hubungan antara sesama manusia, sangat mendapatkan perhatian dalam dunia pendidikan agama. Nilia-nilai tersebut pada dasarnya harus tertanam di dalam hati seseorang atau peserta didik yang kemudian ketika diimplementasikan dalam kehidupan sehari-hari akan menjadi kebaikan atau kesalehan sosial. Nilai-nilai tersebut misalnya, kejujuran, respek (menghargai orang lain), toleran, disiplin, kerja keras, dan lain sebagainya.

Kalau diperhatikan sebenarnya banyak sekali nilai-nilai etika yang diajarkan oleh agama Islam (al-Qur'an dan Hadits). Nilai tentang keadilan, ta'awun (tolong menolong), shidiq, amanah, terpuji, nilai manfaat, respek (menghargai orang lain), tangung jawab (responsibility), yukrim dhoifah (menghormati tamu), yukrim jarohu (menghormati tetangga), satr al uyyub (menutupi aib orang lain), dan masih banyak lagi nilai-nilai etika yang lain. Semuanya itu merupakan ajaran agama dan sekaligus juga merupakan perilaku etis individual yang merefleksi dalam kehidupan sosial atau berdampak kepada kehidupan sosial dengan landasan niulainilai ajaran agama Islam. Selanjutnya yang menjadi pertanyaan ialah mengapa nilai-nilai etika sosial tadi belum dapat terwujud dalam kehidupan sehari-hari dalam sebuah sistem sosial kita, padahal mayoritas masyarakat Indonesia beragama Islam. Terjadinya kesenjangan antara norma, atau ajaran Islam dengan perilaku keseharian tersebut paling tidak menjadi tanggung jawab dari pendidikan agama. Atau paling tidak harus

${ }^{6} \mathrm{H}$. Burhanuddin Salam, Etika Individual Pola Dasar Filsafat Moral, (Yogyakarta:Renika Cipta, 2000), 35

${ }^{7}$ Frans Magnis Susena, Etika Sosial, (Jakarta: Gramedia, 1996), 50 
ada pemecahan terhadap masalah tersebut melalui pendidikan agama. Bagaimana pendidikan agama dapat mengintegrasikan etika sosial tersebut di dalamnya.

\section{LANDASAN YURIDIS PENDIDIKAN AGAMA ISLAM}

Menarik untuk disimak keberadaan pendidikan agama di dalam negara Republik Indonesia yang sejak semula diproklamasikannya negara ini, pendidikan agama itu telah ada dalam sekolah negeri yang diatur oleh pemerintah dengan peraturan perundangan.

Sampai hari ini pendidikan agama itu masih tetap ada sebagai mata pelajaran yang berdiri sendiri untuk semua jenjang dari TK sampai perguruan tinggi dan merupakan kategori mata pelajaran pokok. Dan ini bisa terjadi berkat perjuangan dan usaha para pemimpin Islam pada waktu yang dengan kecekatan dan kesadaran akan makna strategi dan pentingnya pelajaran agama harus masuk ke sekolah-sekolah negeri. Sampai akhirnya berkat perjuangan beliau-beliau para pendiri bangsa pendidikan agama tercantum dalam dokumen negara seperti UU, PP, GBHN, TAP-MPR, Keputusan Menteri dan lain-lain. Yang selanjutya disebut landasan yuridis pendidikan agama Islam.

Yang dimaksud landasan yuridis di sini adalah kekuatan hukum yang mendasari pelaksanaan Pendidikan Agama Islam di Indonesia. Karena negara kita adalah negara hukum, maka seluruh aspek kehidupan termasuk kegiatan pendidikan agama harus didasarkan pada ketentuan dan perundang-undangan yang berlaku. ${ }^{8}$

Negara Republik Indonesia adalah negara Pancasila, bukan negara sekuler, theokrasi ataupun negara atheis. Dalam negara Pancasila, "Negara menjamin kemerdekaan tiap-tiap penduduk untuk memeluk agamanya masing-masing dan beribadat menurut agamanya dan kepercayaannya itu" (Pasal 29 ayat 2 UUD 1945). Berdasarkan pasal ini, negara jelas menjamin kelangsungan dan praktek keagamaan dalam semua segi kehidupan termasuk dalam kehidupan pendidikan'. Bahkan pendidikan agama

${ }^{8}$ H Ahmadi, "Dasar-Dasar Pelaksanaan Pendidikan Agama Islam Di Sekolah" dalam HM Chabib Thoha (Ed), PBM PAI Di Sekolah, (Yogyakarta; Pustaka Pelajar, 1998), 58

${ }^{9}$ H. Alamsyah Ratu Perwiranegara, Pembinaan Pendidikan Agama, Jakarta; Depag RI, 1982), 31 
tidak dapat dipisahkan dari kehidupan pendidikan di Indonesia. ${ }^{10} \mathrm{Hal}$ ini karena pembinaan moral bangsa yang dibimbing menurut petunjuk agama akan menjamin keselamatan kemajuan yang telah dicapai dalam bidang materiil. Kemajuan iptek tanpa diimbangi kemampuan manusia untuk menguasi diri sendiri akan mengancam dan membahayakan diri sendiri dan bangsa. Kemampuan pengendalian diri ini pada dasarnya merupakan salah satu aspek dari tujuan pendidikan agama. ${ }^{11}$

Melihat begitu pentingnya peranan pendidikan agama dalam kehidupan berbangsa dan bernegara, maka pemerintah Indonesia sejak masa orde lama telah mengeluarkan berbagai kebijakan tentang pendidikan agama ini. UU RI No. 4 Tahun 1950 tentang Dasar-Dasar Pendidikan Dan Pengajaran Di Sekolah pasal 20 menyebutkan :

1. Dalam sekolah-sekolah negeri diadakan pelajaran agama; Orang tua murid menetapkan apakah anaknya akan mengikuti pelajaran tersebut.

2. Cara menyelenggarakan pelajaran agama di sekolah-sekolah negeri diatur dalam peraturan yang ditetapkan oleh Menteri Pendidikan, Pengajaran dan Kebudayaan bersama-sama dengan menteri Agama.

Sementara itu dalam pasal tersebut dijelaskan :

1. Apakah suatu jenis sekolah memberi pelajaran agama adalah bergantung pada umur dan kecerdasan murid-muridnya.

2. Murid-murid yang sudah dewasa boleh menetapkan ikut dan tidaknya pelajaran agama.

3. Sifat pengajaran agama dan jumlah jam pelajaran ditetapkan dalam undang-undang tentang jenis sekolahnya.

4. Pelajaran agama tidak mempengaruhi kenaikan kelas. ${ }^{12}$

Dari bunyi pasal tersebut di atas, nampaknya pendidikan agama masih lemah dasar hukumnya. Hal ini bisa dilihat dari antara lain; Hanya

10 Ibid, .35 .

${ }^{11}$ Ibid, 55-56

12 UU No. 12 Tahun 1954 tentang Pernyataan Berlakunya UU NO.4 Tahun 1950, Lampiran dalam I Djumhur dan H. Danasaputra, Sejarah Pendidikan, (Bandung; CV Ilmu, 1974), 257. 
sekolah negeri saja yang diatur dalam UU ini, sifat pendidikan agama masih suka rela belum menjadi mata pelajaran wajib, dan pendidikan agama sama sekali tidak dipertimbangkan dalam penentuan kenaikan kelas bagi siswa yang bersangkutan. Meskipun demikian, dicantumkannya pendidikan agama dalam UU ini bukan berarti tidak melewati proses yang panjang. Keinginan umat Islam agar pelajaran agama diberikan di sekolahsekolah telah diperjuangkan oleh wakil-wakil Islam pada BP KNIP yang berfungsi sebagai parlemen pada saat itu, yakni tidak lama setelah Indonesia merdeka. ${ }^{13}$

Sebagai tindak lanjut dari pasal 20 ayat (1) UU No 4 Tahun 1950 tersebut, dikeluarkanlah Peraturan Bersama Menteri Pendidikan, Pengajaran dan Kebudayaan dan Menteri Agama No. 17678/kab/1951 dan No. k/1/9180/1951 tentang Peraturan Pendidikan Agama Di Sekolah-Sekolah Negeri yang ditetapkan pada tanggal 16 Juli 1951.

Kedudukan pendidikan agama menjadi kuat setelah dikeluarkannya TAP MPRS No. II / MPRS / 1960 yang dipertegas oleh TAP MPRS No. XXVII / MPRS/ 1966. Dalam pasal 2 ayat (3) Tap MPRS itu disebutkan; "Menetapkan pendidikan agama menjadi mata pelajaran di sekolah-sekolah dasar sampai dengan universitas negeri. ${ }^{14}$ Dan pada masa selanjutnya GBHN selalu mengamanatkan tentang pentingnya pendidikan agama.

Lahirnya UU No. 2 Tahun 1989 Tentang Sistim Pendidikan Nasional (UUSPN) merupakan angin segar bagi dunia pendidikan di Indonesia. Hal ini karena dalam UUSPN termasuk beberapa Peraturan pemerintah (PP) yang menyertainya telah memuat basic guidance pelaksanaan pendidikan di Indonesia. Secara mendasar UUSPN sama sekali tidak mengabaikan keberadaan pendidikan agama. Hal ini bisa dilihat dari tujuan pendidikan nasional (pasal 4) yang menginginkan terbentuknya "manusia Indonesia seutuhnya, yaitu manusia yang beriman dan bertakwa terhadap Tuhan YME dan berbudi pekerti yang luhur, memiliki pengetahuan dan keterampilan, kesehatan rohani dan jasmani, kepribadian yang mantap dan mandiri serta rasa tanggung jawab kemasyarakatan dan kebangsaan". Manusia yang beriman dan bertakwa terhadap Tuhan YME hanya akan terwujud melalui pendidikan agama.

13 Muhammad Zein, "Pendidikan Agama Dalam UU No. 4 Tahun 1950 dan UU No. 2 Tahun 1989" dalam Jurnal Ilmu Pendidikan Islam, vol. I, 1991, Yogyakarta; Fak. Tarbiyah IAIN Sunan Kalijaga, 1991,64.

${ }^{14}$ Ibid,. 69. 
Oleh karena itu, secara konsisten UUSPN mengakui keberadaan lembaga pendidikan keagamaan (pasal 11) dan pendidika agama itu sendiri. Bahkan pendidikan agama merupakan salah satu dari isi kurikulum yang wajib dimuat dalam setiap jenis, jalur dan jenjang pendidikan disamping pendidikan Pancasila dan pendidikan kewarganegaraan (pasal 39 ayat 2).

Selaian di atas, keberadaan PAI dalam keseluruhan isi kurikulum sekolah umum juga telah dijamin oleh UU No. 20 Tahun 2003 tentang Sistem Pendidikan Nasional bab X pasal 37 "Kurikulum pendidikan dasar dan menengah wajib memuat: a. pendidikan agama, Bahkan PAI merupakan salah satu mata pelajaran wajib yang harus diajarkan di setiap jalur, jenis dan jenjang pendidikan baik negeri maupun swasta. Dalam hal ini pendidikan agama diharapkan dapat memberi nafas bagi setiap bidang studi yang diajarkan kepada peserta didik, serta mampu berperan untuk menciptakan kehidupan beragama yang harmonis di setiap sekolah pada semua jenjang pendidikan.

Dari uraian di atas, dapat disimpulkan bahwa eksistensi pendidikan agama di sekolah umum baik sebagai suatu aktifitas maupun sebagai salah satu mata pelajaran mempunyai dasar hukum yang sangat kuat. Oleh karena itu, rasanya aneh jika ada sebagian pihak yang mengusulkan agar pendidikan agama dihapus saja dari sekolah dengan alasan hanya menambah beban mata pelajaran yang harus dikuasai siswa, lagi pula masalah agama dan kepercayaan adalah masalah pribadi yang terutama menjadi tanggung jawab orang tua siswa bersangkutan.

Inti dari semua itu, jika negara ini telah disepakati sebagai negara berketuhanan, baik buruk moralitas bangsa ini tidak lepas dari tanggung jawab pemerintah. Ini berarti bahwa sistem dan kebijakan pemerintah di segala bidang harus senantiasa berdasar pada prinsip ketuhanan yang kondusif bagi pembinaan moralitas bangsa. Sistem pendidikan nasional adalah salah satu di antara sekian sistem yang berhubungan dengan pembinaan moral bangsa. ${ }^{15}$

Pendidikan agama di sekolah-sekolah negeri dan swasta memiliki landasan konstitusional yang kuat harus tetap dipertahankan dan dikembangkan sehingga efektif dalam mendukung pembinaan moral bangsa.

${ }^{15}$ Hamid Fahmy, ,'Negara, Pendidikan Agama, Moralitas Bangsa , 53. 


\section{PENDIDIKAN AGAMA DAN REALITA KEHIDUPAN}

Di tengah perkembangan ilmu pengetahuan dan teknologi dan perubahan sosial budaya yang telah, sedang dan akan terus dirasakan umat manusia dihadapkan pada dua kenyataan, yaitu antara harapan dan kecemasan. Harapan, karena bisa memanfaatkan temuan-temuan di bidang iptek untuk hal-hal positif yang bisa menunjang eksistensi kehidupan manusia di muka bumi. Oleh karena itu, segala upaya ditempuh untuk mengejar ketertinggalan di bidang iptek ini. Namun, pada sisi yang lain, perkembangan iptek juga membawa konsekuensi negatif pada perubahan sosial budaya yang kadang memporakporandakan tata nilai yang telah ada, sehingga membuat manusia cemas.

Kecemasan tersebut adalah suatu hal yang wajar mengingat arus kehidupan yang semakin modern yang memungkinkan terjadinya dereligionazation. Penelitian Lucy E. Creevey di Senegal yang menyimpulkan bahwa arus modernisasi mempunyai dampak negatif terhadap kehidupan agama.16 Modernisasi ternyata telah melahirkan suasana hidup yang penuh keterasingan dan ketidakselarasan serta perubahan tingkah laku agama yang mengarah pada sekularistik.

Di sisi lain arus kehidupan modern dengan berbagai dampak negatifnya justru manusia nampak lebih lengket terhadap agama. Lebihlebih dalam beberapa tahun terakhir ini, ada kecenderungan orang untuk kembali pada agama. Di mana-mana orang berbicara tentang agama, baik sebagai falsafah kehidupan maupun dalam kaitannya dengan ilmu.17 Tujuannya adalah bukan mengislamkan ilmu, melainkan memberikan nafas agama kepada ilmu.

Fenomena ini menurut Kuntowijoyo18 corak kehidupan yang semakin lengket terhadap agama diartikan sebagai kesadaran balik akibat modernisasi yang sering menimbulkan suasana keterasingan dan ketidakselarasan.

16 Lucy E. Creevy, "Religion and Modernization in Sinegal" dalam John L. Esposito, ed., Islam and Development: Religion and Sosiopolitical Chance, (New York: Syracuse University Press, 1980), 207-221.

17 Rohmat Mulyana, Membangun Bangsa Melalui Pendidikan, (Bandung: Remaja Rosdakarya, 2004), 126

${ }^{18}$ Kuntowijoyo, Budaya dan Masyarakat, (Yogyakarta: Tiara Wacana, 1987), 81-96. 
Maka untuk mengatasi kesenjangan antara harapan pada satu sisi dan kecemasan pada sisi yang lain, nampaknya manusia masih memerlukan peran agama sebagai panduan moral dan sumber tata nilai. Di sini pendidikan agama (Islam) memegang peranan penting dalam rangka internalisasi dan sosialisai ajaran dan nilai-nilai agama.19 Dengan harapan pendidikan agama yang kuat seseorang akan sulit digoyahkan oleh dampak modernisasi yang negatif.

Mengapa pendidikan agama masih sangat diperlukan dalan kehidupan yang modern ini, menurut pandangan fungsionalis, sedikitnya ada lima fungsi sosial agama, yaitu fungsi solidaritas sosial, fungsi memberi arti hidup, fungsi kontrol sosial, fungsi dukungan psikologis dan fungsi perubahan sosial.20 Fungsi solidaritas sosial tercermin ketika agama berfungsi sebagai perekat sosial yang menghimpun para pemeluknya untuk secara teratur melakukan berbagai ritual yang sama, berpedoman dengan nilai yang sama dan di atasnya dibangun komunikasi yang sama. Agama juga bisa memberi arti hidup karena mampu memberikan jawaban terhadap persoalan-persoalan ultimate dan eternal yang dihadapi manusia mengenai keberadaannya di dunia ini. Pada satu sisi, nilai dan norma agama akan membantu memelihara kontrol sosial dengan mengendalikan tingkah laku para individu pemeluknya. Pada sisi yang lain, agama juga memberikan dukungan psikologis kepada pemeluknya ketika ia menghadapi cobaan dan goncangan dalam kehidupannya. Di samping itu, agama juga bisa memberikan inspirasi dan melicinkan jalan bagi perubahan sosial. Melihat begitu strategisnya fungsi dan peran agama dalam kehidupan sosial ummat manusia, maka adalah suatu yang niscaya, jika eksistensi pendidikan agama termasuk Pendidikan Agama Islam di jamin dalam peraturan perundang-undangan di negara kita.

Kesadaran akan pentingnya nilai-nilai agama dan moral dalam kehidupan masyarakat Indonesia memberikan peluang yang sangat besar kepada dunia pendidikan untuk merealisasikannya. Ini berarti kesempatan emas bagi umat Islam untuk menjadikan pendidikan sebagai pilihan strastegis bagi pemeliharaan, penanaman dan penyebaran nilai-nilai Islam

19 Disarikan dari tulisan Moctar Buchori, Penelitian Pendidikan dan Pendidikan Islam, (Jakarta: IKIP Muhammadiyah Jakarta Press, 1994), 72-82.

${ }^{20}$ HM Atho Mudzhar, "Guru PAI dalam Perspektif Tantangan Hidup Beragama" dalam Media Edisi 16/III/Nop 1993, (Semarang; fak. Tarbiyah IAIN Walisongo, 1993), 6-7. 
dalam kehidupan masyarakat Indonesia. Konsekuensinya, diperlukan upaya-upaya yang dinamis, fleksibel dan serius dalam menggarap dunia pendidikan.

Fenomena di Indonesia kegiatan pendidikan yang dilaksanakan oleh umat Islam atau apa yang sering disebut dengan pendidikan Islam menjangkau semua interaksi edukatif, baik melalui jalur sekolah maupun luar sekolah. Kegiatan pendidikan Islam melalui jalur luar sekolah antara lain tercermin dalam kegiatan majelis taklim, pengajian, pondok pesantren dan lain-lain. Sementara pendidikan Islam melalui jalur sekolah antara lain diwujudkan dalam bentuk lembaga pendidikan Islam formal seperti MI, MTs, MA, IAIN/STAIN/PTAIS, juga diwujudkan dalam bentuk mata pelajaran Pendidikan Agama Islam (PAI) di lembaga pendidikan (sekolah) umum. Keberadaan PAI dalam keseluruhan isi kurikulum sekolah umum memang dijamin oleh UU No. 20 Tahun 2003 tentang Sistem Pendidikan Nasional bab X pasal 37. Bahkan PAI merupakan salah satu mata pelajaran wajib yang harus diajarkan di setiap jalur, jenis dan jenjang pendidikan baik negeri maupun swasta.

Ini artinya pendidikan agama diposisikan sebagai bidang studi wajib di lembaga-lembaga pendidikan formal. Sifat wajib pendidikan agama di lembaga-lembaga pendidikan masih dikuatkan dengan pola yang confessional. Atau yang dikenal dengan confessional religious education ${ }^{21}$ yaitu pendidikan agama yang bertujuan menanamkan rasa keimanan dalam diri subyek didik terhadap suatu agama tertentu.22 Dengan pola ini peserta didik diharapkan mempunyai kebribadian yang dicita-citakan oleh tiap-tiap agama.

Akan tetapi, kendati pendidikan agama merupakan wajib disemua jenjang sekolah, tetapi pendidikan agama tidaklah cukup dibebankan pada sekolah-sekolah formal saja melainkan harus dibantu dengan pendidikan luar sekolah dan pendidikan dalam keluarga, berupa pengajian dan kursus

21 Pola sebaliknya lazim disebut dengan non-confessional religious education. Maksudnya adalah pendidikan agama yang tidak bertujuan untuk menanamkan rasa keimanan terhadap agama tertentu, tetapi untuk membantu subyek didik agar secara peka menyadari adanya berbagai kepercayaan yang diyakini oleh kelompok-kelompok dalam masyarakatnya. Jadi pelajaran agama hanya untuk sekedar ilmu pengetahuan sebagaimana mata pelajaran lainnya.

22 Basil Moore, "The Nature of Religious Education" dalam Graham R. Rossiter, Religious Education in Australian School, (Camberra: Curriculum Development Centre, 1981), 160 
agama lainnya. Pendidikan agama bukan sekedar mengejar nilai/prestasi yang tinggi tetapi lebih dari itu berupa penghayatan dan pengamalan serta pembentukan kepribadian dari nilai-nilai yang terkandung dalam ajaran agama itu.

Pendidikan pada dasarnya adalah proses rekayasa atau rancang bangun kepribadian manusia. ${ }^{23}$ Oleh karena itu, kedudukan manusia dalam proses pendidikan menjadi sangat sentral. Pernyataan di atas mengandung dua implikasi. Pertama, pendidikan perlu mempunyai dasardasar pemikiran filosofis yang memberi kerangka pandang yang holistik tentang manusia atau peserta didik. Kedua, dalam seluruh prosesnya, pendidikan perlu meletakkan manusia sebagai titik tolak, sekaligus titik tujuan dengan pandangan kemanusiaan yang telah dirumuskan secara filosofis.

Dalam pandangan Islam manusia sebagai titik sentral dalam proses pendidikan. Islam mendudukkan manusia sebagai "hamba Allah" dan "wakil/pengganti Allah di muka bumi". Konsep manusia sebagai hamba Allah, lebih banyak mengacu pada tugas-tugas individual manusia sebagai hamba Allah. Tugas ini berwujud ritual (ibadah). (al-Qur`an: 51. (QS. Adz Dzariyat 56). Sedang konsep manusia sebagai khalifah Allah (al-Qur`an: 1:31) memberikan gambaran bahwa seolah-olah Allah mempercayakan kakuasaan-Nya kepada manusia untuk mengemban tugas dan tanggung jawab yang besar yang dalam pelaksanaannya menuntut komitmen moral spiritual yang tinggi, yaitu memakmurkan bumi (al-Qur`an: QS. Hud 61), mengembangkan risalah menegakkan segala amal yang mengandung kemaslahatan, kebenaran dan keadilan (alQur`an: Al-Mulk 2). Tugas dan tanggung jawab yang diberikan kepada manusia oleh Allha (al-Qur'an: Al Ahzab 72) sebagai 'amanat' yang harus diterima oleh manusia. Konsep manusia yang seperti di atas, menjadi sangat relevan untuk pemberdayaan fungsi manusia sebagai makhluk sosial. Maka berdasar kerangka berfikir seperti di atas pendidikan dapat diartikan sebagai proses penyadaran akan fungsi-fungsi manusia sebagai hamba Allah dan khalifah Allah.

Berdasar kerangka berpikir seperti di atas maka hakekat dari pendidika-seperti juga sering disampaikan oleh para pakar pendidikan-

23 Mohammad Irfan-Mastuki HS, Teologi Pendidikan, Jakarta: Friska Agung Insani, 2000), 16. 
adalah memanusiakan manusia. Pernyataan ini sejalan dengan pokok pikiran di atas yaitu proses penyadaran akan akan fungsi-fungsi manusia sebagai hamba Allah dan khalifah Allah.

Istilah pendidikan dalam al-Qur'an, dikenal tarbiyah, ta'lim, dan ta' $^{\prime} i^{24}{ }^{24}$. Meskipun istilah ta'dib tidak digunakan sebagai term dalam alQur'an untuk menjelaskan masalah pendidikan Islam, bukan berarti bahwa konsep pendidikan Islam tidak menyentuh aspek ta'dib ini. Sebab essensi dari sistem pendidikan adalah perbaikan moral. Di dalam istilah ta'dib terdapat beberapa arti, yakni: pendidikan, ketertiban, hukuman, hukuman demi ketertiban. Semuanya menunjukkan bahwa istilah ini lebih mengarah kepada perbaikan tingkah laku. Dengan demikian, kalau di atas telah dijelaskan bahwa essensi dari pendidikan adalah sebagai proses penyadaran akan fungsi-fungsi manusia sebagai hamba Allah dan wakil Allah, maka arah dari pendidikan Islam itu sebenaranya adalah perbaikan moral dan tingkah laku manusia. Untuk itu, dapat ditarik kesimpulan bahwa di dalam pelaksanaan pendidikan Islam terdapat usaha-usaha pembentukan etika sosial.

Membicarakan tentang pendidikan agama memang telah cukup lama mendapat perhatian dari para tokoh dan telah melahirkan banyak pemikiran dan kebijakan yang diambil dalam rangka peningkatan kualitas pendidikan agama. Wujud dari upaya tersebut nampak pada munculnya berbagai pemikiran dan kebijakan tentang pembinaan terpadu pendidikan agama di sekolah umum, madrasah, pondok pesantren, dan lain sebagainya. Tetapi juga tidak menutup mata bahwa permasalahan yang terkait dengan pendidikan agama belum seluruhnya tuntas. Akhir-akhir ini banyak pihak yang mempertanyakan tentang efektivitas pendidikan agama apabila dikaitkan dengan gejala degradasi moral atau kekeringan nilai di kalangan masyarakat. Oleh karena itu, adalah sesuatu yang wajar apabila sekarang muncul anggapan yang negatif-atau lebih tepatnya penilaian kritis-terhadap pelaksanaan pendidikan agama (khususnya di sekolah) dari masyarakat atau para ahli pendidikan. Penilaian kritis terhadapa pendidikan agama, dapat dijelaskan sebagai berikut:

1. Islam diajarkan lebih pada hafalan (padahal Islam penuh dengan nilainilai yang harus dipraktekkan).

24 Musthafa Rahman, Pendidikan Islam Dalam Prospektif Al-Qur'an, dalam Paradigma Pendidikan Islam, (Yogyakarta: Pustaka Pelajar, 2001), 34. 
2. Pendidikan agama lebih ditekankan pada hubungan formalitas antara hamba dan Tuhan.

3. Penalaran dan argumentasi berpikir untuk masalah-masalah keagamaan kurang mendapatkan perhatian.

4. Penghayatan nilai-nilai agama kurang mendapatkan penekanan.

5. Menatap lingkungan untuk kemudian memasukkan nilai-nilai Islam sangat kurang mendapatkan perhatian.

6. Methode pembelajaran agama, khususnya yang berkaitan dengan nilainilai Islam kurang mendapat penggarapan.

7. Ukuran keberhasilan pendidikan agama juga masih formalitas (termasuk verbalis).

8. Pendidikan agama belum mampu menjadi landasan kemajuan dan kesuksesan untuk mata pelajaran lain.

9. Pendidikan agama belum dijadikan fondasi pendidikan karakter anak didik dalam perilaku keseharian.

Lebih lanjut dijelaskan bahwa pendidikan agama pada prinsipnya juga hampir sama dengan pola umum pendidikan, yakni sebagai pengembangan potensi yang terpendam dalam diri anak peserta didik yaitu: nilai (value), pengetahuan (knowledge), dan ketrampilan (skill). Menurut Taxonomi Bloom, ada tiga ranah yang harus diperhatikan oleh pendidik dalam proses pendidikan, yakni ranah kognitif (cognitive domain), ranah afektif (affective domain), dan ranah psikomotorik (psycomotoric domain). Tetapi di dalam kenyataannya, bahwa pelaksanaan proses pembelajaran pendidikan agama, terlalu menitik beratkan kepada aspek kognitif, kurang menyentuh aspek psikomotorik, lebih-lebih pada aspek afektif ${ }^{25}$. Artinya di dalam proses pembelajaran pendidikan agama, kurang melatih dan menanamkan jiwa dan sikap beragama. Anak didik mudah saja hafal di luar kepala tentang rukun-rukun shalat, rukun wudu dan hal-hal yang membatalkan shalat dan wudu dan lain sebagainya. Pembelajaran yang demikian, menjadikan peserta didik ketika memasuki realitas kehidupan, mereka tidak memiliki kemampuan untuk melaksanakan ajaran agama, karena peserta tidak menjiwai ajaran agamanya, sehingga wajar kalau

${ }^{25}$ Saifudin Zuhri, Dialog Fungsional Pendidikan Islam dan UUSPN Tabun 1989, dalam Raradigma Pendidikan Islam, (Yogyakarta: Pustaka Pelajar, 2001), 21. 
banyak sekali perilaku negatif dilakukan oleh pelajar dan remaja yang notabene beragama Islam.

\section{E. PENGEMBANGAN ETIKA SOSIAL MELALUI DESAIN INSTRUKSIONAL PAI KONTEMPORER}

Upaya peningkatan fungsionalisasi pendidikan agama dengan pendekatan pengembangan etika sosial, harus berangkat dari suatu pemahaman bahwa pokok persoalan pendidikan agama bukan terletak pada ajaran keimanan dan ibadah saja, tetapi masalah pokok pendidikan agama juga terletak pada hubungan horizontal (bablum minan nas), dan apresiasinya terhadap ajaran akhlak. Oleh karena itu etika sosial harus mendapatkan perhatian lebih serius dari para pendidik, karena selama ini materi etika sosial sering diabaikan. Materi-materi yang berhubungan dengan kebersihan (thoharoh nadrofah), ketepatan waktu/menghargai waktu (Al Ashr), tanggung jawab (nas'uliyah), menepati janji, dan lain sebagainya merupakan materi-materi yang dapat dikembangkan untuk memupuk perasaan etika sosial.

Berbagai kritikan yang di alamatkan pada proses pendidikan agama di sekolah, sudah seharusnya menjadi perhatian serius bagi para pendidik agama. Oleh karena itu, sudah saatnya dikembangkan suatu desain pembelajaran yang PAI yang efektif dan sesuai dengan kebutuhan peserta didik di masa kekinian atau kontemporer. Desain PAI kontemporer adalah sistem dan desain pembelajaran PAI yang terpengaruh dampak modernisasi dan tidak lagi dilakukan secara tradisional yang selama ini terjadi. Kontemporer dapat diartikan kekinian, modern atau lebih tepatnya adalah sesuatu yang sama dengan kondisi waktu saat ini ${ }^{26}$. Dengan demikian pembelajaran kontemporer adalah pembalajaran yang tidak terikat oleh aturan-aturan zaman dulu dan sudah berkembang sesuai zaman sekarang. Sistem dan desain pembelajaran didesain secara tematik merefleksikan situasi waktu yang sedang dilalui dan tampak lebih kreatif dan modern. Desain pembelajaran PAI kontemporer berusaha untuk meningkatkan kecerdasan afektif, kognitif dan psikomotrik, serta mengakomodasi berbagai terori, metode, media dan sumber-sumber belajar. Hal ini menuntut para pendidik untuk lebih kreatif mencari

${ }^{26}$ Jonh M. Echol dan Hassan Shadili, Kamus Inggris Indonesia, (Jakarta: PT Gramedia Pustaka Utama, 1993), 143. 
pendekatan baru dalam mengembangkan sistem dan desain instruksionalnya.

Model pembelajaran kontemporer merupakan suatu rencana mengajar yang memperhatikan pola pembelajaran tertentu, hal ini sesuai dengan pendapat Briggs yang menjelaskan model adalah "seperangkat prosedur dan berurutan untuk mewujudkan suatu proses" ${ }^{27}$. Model-model pembelajaran kontemporer berkembang sesuai dengan perkembangan kebutuhan peserta didik. Pendidik profesional dituntut mampu pengembangkan model pembelajaran, baik teoritik maupun praktek, yang meliputi aspek konsep, prinsip, dan teknik. Memilih model pembelajaran yang tepat merupakan persyaratan untuk membantu peserta didik dalam rangka mencapai tujuan pembelajaran. Model pembelajaran berpengaruh secara tangsung terhadap keberhasilan belajar siswa. Pemelihan model pembelajaran sebagai suatu strategi pembelajaran, hendaknya memperhatikan lima aspek kunci dari pembelajaran yang efektif, yaitu: (1) kejelasan, (2) variasi, (3) orientasi tugas, (4) keterlibatan siswa dalam belajar, dan (5) pencapaian kesuksesan yang tinggi.

Selanjutnya Briggs mengemukakan ada empat rumpun model pembelajaran kontemporer, yakni; (1) rumpun model interaksi sosial, yang lebih berorientasi pada kemampuan memecahkan berbagai persoalan sosial kemasyarakat. (2) Model pemorosesan informasi, yakni rumpun pembelajaran yang lebih berorientasi pada pengusaan disiplin ilmu. (3) Model pengembangan pribadi, rumpun model ini lebih berorientasi pada pengembangan kepribadian peserta belajar. Selanjutnya model (4) behaviorism yang dimaknai oleh Briggs yakni model yang berorientasi pada perubahan perilaku. Berdasarkan kajian yang penulis lakukan terhadap beberapa model pembelajaran yang dapat meningkatkan kualitas proses dan hasil pembelajaran pendidikan agama Islam, di antaranya adalah: model classroom meeting, cooperative learning, integrated learning, constructive teaming, inquiry learning, dan quantum learning. ${ }^{28}$

Secara spesifik, sistem pendidikan Islam berbeda dengan pendidikan lainnya, bahkan bisa dikatakan lebih unggul daripada sistem pendidikan non-Islam, hal ini dikarenakan sistem pendidikan Islam

${ }^{27}$ Lesslie Briggs, Instructional Design. (New Jersey: Ed. Techn. Publ, 1978), 23.

${ }^{28}$ Lesslie Briggs, Instructional Design, 40 
memiliki dua model sistem, yaitu: (1) model idealistis dan (2) model pragmatis

1. Model Idealistik

Model ini adalah model yang lebih mengutamakan penggalian sistem pendidikan Islam dari ajaran-ajaran Islam sendiri, yaitu al-Qur an dan Hadis yang mengandung prinsip-prinsip pokok berbagai aspek kehidupan termasuk aspek pendidikan. Dalam sejarah Islam dapat dijumpai bahwa dasar-dasar pembentukan dan pengembangan pendidikan Islam yang pertama dan utama adalah al-Qur`an dan Sunnah. Model ini menggunakan pola deduktif, dengan membangun premis mayor (sebagai postulat) yang dikaji dari nash. Bangunan premis mayor ini dijadikan sebagai "kebenaran universal dan mutlak" untuk diterapkan pada premis minornya. Dari proses ini akhirnya mendapatkan konklusi mengenai sistem pendidikan Islam.

\section{Model Pragmatis}

Model ini pragmatis ini adalah model yang lebih mengutamakan aspek praktis dan kegunaannya. Artinya, formulasi sistem pendidikan Islam itu diambil dari sistem pendidikan kontemporer yang telah mapan. Apa saja yang terdapat pada pendidikan kontemporere dapat dikembangkan dalam pendidikan Islam, selama tidak bertentangan dengan prinsip-prinsip dasar yang terdapat dalam al-Quran dan Sunnah. Dalam rangkan pengembangan sistem Pendidikan Islam, Model ini dapat dilakukan dengan cara: (1) adopsi, yaitu mengambil secara utuh sistem pendidikan komtemporer yang telah mapan atu non-Islam, (2) asimilasi yaitu mengambil sistem pendidikan non-Islam dengan menyesuaikannya di sana sini, dan (3) legitimasi yaitu mengambil sistem pendidikan non-Islam kemudian dicarikan nash untuk yudisfikasinya.

Model pragmatis ini paling banyak diminati para pakar pendidikan Islam, di samping efektifitas dan efisiensinya, model ini telah teruji keunggulannya. Sistem pendidikan Islam yang dikembangkan melalui model ini memiliki posisi tersendiri bahkan mampu menjadi alternatif bagi keberadaan sistem pendidikan Islam kontemporer.

Sistem pendidikan Islam yang didasarkan pada model ini bersumber dari pemikiran filsafat psikologi kontemporer. Sistem pendidikan yang terdapat di dalam aliran progresivisme, esensialisme, perenialisme, dan rekonstruksionisme. Namun demikian, bukan berarti 
orientasi pendidikan Islam sama dengan pendidikan Barat yang mengukur kebenaran menurut kebenaran waktu, tempat dan situasi, dan berakhir pada garis hayat, akan tetapi pendidikan Islam berorientasi kepada duniawi dan uhkrawi. Di dalam Islam kehidupan akhirat merupakan kelanjutan dari kehidupan dunia, karena Islam merupakan agama universal yang berisi ajaran-ajaran yang dapat membimbing manusia kepada kebahagiaan hidup di dunia dan akhirat.

Mengajarkan nilai dan mendidik perilaku yang lebih mengarah pada ranah afektif maupun psikomotor, nampaknya berbeda dengan mengajar materi yang lebih menitik beratkan kepada aspek kognitif. Pelaksanaan pendidikan untuk yang terakhir, lebih kepada transfer of knowledge sehingga perencanaan pengajarannya disusun berdasar faktafakta yang harus dipahami dan bahkan juga harus dihafal. Dan pengukurannyapun menjadi lebih mudah karena dapat dari hasil pemahaman dan hafalan fakta-fakta yang harus dikuasai. Berbeda dengan mengajarkan materi 'nilai' dan perilaku, maka aspek yang dominan ialah pada aspek afekti dan psikomotorik (transfer of value). Dari perspektif pendidikan nilai, misalnya guru di dalam kelas tidak cukup dengan mengajarkan materi pada tataran normatif kemudian ditagih dengan melalui ujian dan hafalan.

Di sini dikemukakan beberapa alternatif upaya agar pendidikan agama lebih bermutu lewat pendekatan pengembangan etika sosial.

1. Guru pendidikan agama dituntut untuk menciptakan metode baru sekaligus melaksanakan: a. Creating a moral community in the classroom (menciptakan suatu masyarakat/ kelompok bermoral di kelas), b, moral diciplin, c. Creating a democratic classroom enviroment ( menciptakan lingkungan ruang kelas yang demorakratis), d. Teaching values trhough the curriculum (mengajarkan nilai melalui kurikulum), e. Encouraging moral reflection (mendorong refleksi moral), $f$. Raising the level of moral discussion (mengangkat tingkatan diskusi moral), g. Teaching children to solve conflict (mengajar anak untuk menyelesaikan konflik).

2. Pendidikan moral harus dilaksanakan secara beriringan dengan antara the morality of teaching (moralitas pengajaran) dan the teaching of morality (pengajaran moralitas). Artinya pendidikan agama mencakup pendidikan moralitas, lantaran agama penuh dengan nilai-nilai moral, dan sekaligus juga moralitas pengajaran, oleh karena itu tidak mungkin mengajarkan nilai moral dengan cara yang tidak bermoral. 
3. Menindak lanjuti pendidikan nilai yang diberikan di sekolah dengan pendidikan moral di dalam keluarga dan lingkungan masyarakat, dibarengi dengan pengawasan yang dilakukan bersama keluarga dan masyarakat. Akan lebih baik apabila nilai-nilai moral itu diarahkan menjadi peraturan atau enforcement (penegakan $\mathrm{n}$ aturan nilai-nilai tadi).

4. Harus ada sistem evaluasi yang terpadu antara hasil penilaian pengetahuan dengan hasil penilaian sikap dan perilaku misalnya lewat sekala sikap, observasi, dan lain sebagainya.

5. Harus dissadari bahwa pendidikan nilai bukan tanpa hambatan. Misalnya terjadinya atau berkembangnya nilai-nilai yang berkembang di masyarakat yang bertentangan dengan apa yang diajarkan di sekolah. Untuk hal yang semacam ini diperlukan keterlibatan dan pengawasan yang terpadu antara sekolah, keluarga dan masyarakat.

6. Dan yang tidak kalah pentingnya adalah peran guru, orang tua, dan tokoh-tokoh masyarakat yang menempatkan dirinya sebagai contoh (role mode), pengasuh (caregiver), dan penasehat (mentor) bagi kehidupan anak didik. 


\section{F. PENUTUP}

Nilai dan ajaran etika sosial yang berangkat dari etika individu, mempunyai akar dan sumber dari ajaran Islam (al-Qur'an dan Hadits). Oleh karena itu perlu ada pelurusan pemahaman dan pemaknaan bahwa pendidikan agama tidak sekedar masalah keimanan dan ubudiyah yang lebih kepada muamalahmaal kholiq (berhubungan dengan sang pencipta), tetapi juga muamalah maal kholqi ( berhubungan dengan makhluq, hubungan antara manusia dan lingkungan). Mengajarkan etika sosial yang berintegrasi di dalam pendidikan agama merupakan keharusan bagi para pendidik agama bersama orang tua dan tokoh-tokoh masyarakat dengan cara yang tepat dengan arah yang jelas.

Oleh karena itu, agar nilai-nilai etika sosial dipegangi oleh peserta didik, maka perlu adanya desain instruksional PAI kontemporer. Maka bagi seorang ruru PAI harus meningkatkan kemampuannya dalam merencanakan desain instruksional dengan: (1) identifikasi masalah berdasarkan kebutuhan, (2) menentukan syarat-syarat dan alternatif pemecahannya, (3) memilih strategi pemecahannya, (4) melaksanakan strategi yang telah dipilih untuk mencapai tujuan instruksionalnya, (5) menentukan efektivitas hasilnya dengan jalan mengadakan evaluasi, dan (6) mengadakan revisi bila perlu pada setiap langkah dari proses tersbut.

Selain itu, guru PAI perlu mendesain pola pengelolaan kelas dengan pendekatan sosio-emotional climate serta mempraktekkan prinsipprinsip pengelolaan kelas yang efektif. Seperti: lebih mengenali karakteristik siswa, merencanakan pembelajaran dengan matang agar kegiatan PBM berjalan dengan efektif dan efisien, melibatkan siswa dalam membuat peraturan dan guru harus bertindak arif. 


\section{DAFTAR PUSTAKA}

Azizy, A Qodri. Pendidikan (Agama) Untuk Membangun Etika Sosial. Semarang: Aneka Ilmu, 2002.

Briggs, Lesslie. Instructional Design. New Jersey: Ed. Techn. Publ. 1978.

Darajad, Zakiah. Pendidikan Agama dalam Pembinaan Mental. Jakarta: Bulan Bintang, 1982.

Echol, Jonh M. dan Shadili, Hassan, Kamus Inggris Indonesia, Jakarta: PT Gramedia Pustaka Utama, 1993.

Hajar, Ibnu. Pendekatan Holistik Dalam Pendidikan Islam, dalam paradigma Pendidikan Islam. Yogyakarta: Pustaka Pelajar, 2001.

Hidayat, Komaruddin. "Agama dan Kegalauan Masyarakat Modern" dalam M. Amin Akkas, Hassan M. Noer ed. Kehampaan Spiritual Masyarakat Modern, Respon dan Transformasi Nilai-nilai Islam Munuju Masyarakat Madani. Jakarta: Media Cita, 2000.

Mastuki, HS, dan Mohammad Irfan. Teologi Pendidikan. Jakarta: Friska Agung Insani, 2000.

Rahim, Husni. Arah Pendidikan Islam di Indonesia. Jakarta: Logos, 2001.

Rahman, Musthafa. Pendidikan Islam Dalam Prospektif Al-Qur'an, dalam Paradigma Pendidikan Islam. Yogyakarta: Pustaka Pelajar, 2001.

Salam, Burhanuddin. Etika Individual Pola Dasar Filsafat Moral. Renika Cipta, 2000.

Susena, Frans Magnis. Etika Sosial. Jakarta: Gramedia, 1996.

Syarif, Ikhwanuddin dan Dodo Murtadlo ed. Pendidikan untuk Masyarakat Indonesia Baru, 70 tabun Prof, Dr. H.A.R. Tilaar, M..Sc.Ed. Jakarta: Grasindo, 2002

Zuhri, Saifudin. Dialog Fungsional Pendidikan Islam dan UUSPN Tabun 1989, dalam Raradigma Pendidikan Islam. Yogyakarta: Pustaka Pelajar, 2001. 